\title{
Nematode diversity indices application to determine the soil health status of Lembo agroecosystem in West Kutai, East Kalimantan Province, Indonesia
}

\author{
SUYADI", SURYA SILA, JEMI SAMUEL \\ Program of Plant Pests and Disease Science, Faculty of Agriculture, Universitas Mulawarman. Jl. Pasir Belengkong, Kampus Gunung Kelua, Samarinda \\ 75119, East Kalimantan, Indonesia. Tel.: +62-541-749161, Fax.: +62-541-738341."email: suyadi @ faperta.unmul.ac.id
}

Manuscript received: 20 April 2021. Revision accepted: 23 June 2021.

\begin{abstract}
Suyadi, Sila S, Samuel J. 2021. Nematode diversity indices application to determine the soil health status of Lembo agroecosystem in West Kutai, East Kalimantan Province, Indonesia. Biodiversitas 22: 2861-2869. Lembo is a typical agroecosystem developed by the people of East Kalimantan, especially in the West Kutai District. Lembo agroecosystems (LA) are generally built on the former of sifting cultivation rice fields. The fertile condition of tropical rainforest land in East Kalimantan, if converted to a rice field agroecosystem, its fertility decreases drastically. However, Lembo is an agroecosystem similar to the forest, and its soil health status in this study was determined by using nematode diversity indices as the indicator. Nematode diversity indices are very useful as indicators because nematodes occupy all positions of the micro food web in the rhizosphere. They can support the increase in soil fertility or pose risks as a pest. This study was aimed to determine the health status of LA soil by using evaluation indicators: (i) nematode absolute abundance, (ii) nematode diversity indices [Shannon-Wiener index $\left(H^{\prime}\right)$, genera richness index (GR), and dominance index $(\lambda)$ ], and (iii) nematode maturity indices ( $\Sigma \mathrm{MI}, \mathrm{MI}, \mathrm{MI}_{2-5}$, PPI, and the PPI/MI-ratio), and using the oil palm plantation (OPP) as the comparison agroecosystem. Based on nematode maturity indices, LA soil health status was categorized as good with MI value $>2.6$, the community abundance of nematode genera in the colonizers' group (c-p2) $\leq 50 \%$, and community abundance of nematode genera in the persisters group (c-p4) $>10 \%$. Then based on the nematode diversity indices $(H$, GR, and $\lambda)$, the LA soil health status was higher than the OPP soil health status, in LA the values of $H^{\prime}$, GR, and $\lambda$ were $30 \%-43 \%, 60 \%-91 \%$, and $12 \%-88 \%$, respectively higher than OPP. The pest status of plant-parasitic nematodes in both agroecosystems is relatively light because their presence is counterbalanced by predatory, carnivore, and omnivore nematodes.
\end{abstract}

Keywords: Agroecosystem, diversity index, Lembo, maturity index, nematodes

Abbreviations: LA: Lembo agroecosystem; OPP: oil palm plantation; GR: genera richness index; $\Sigma \mathrm{MI}$ : total maturity index; MI: maturity index of non-plant parasitic nematodes; PPI: maturity index of plant-parasitic nematodes; $\mathrm{MI}_{2-5}$ : maturity index of nematodes genera group of c-p2-5; $\mathrm{MI}_{2}$ : maturity index of nematodes genera group of c-p2; $\mathrm{ML}_{4}$ : maturity index of nematodes genera group of c-p4

\section{INTRODUCTION}

Lembo is a typical agroecosystem developed by people in West Kutai District and East Kalimantan Province, Indonesia in general. The characteristics of the Lembo agroecosystem are (i) composing of the main crops, i.e., fruit trees (mainly genera of Durio, Artocarpus, Mangifera, Nephelium, and also sugar palm, candlenut, etc.) grown in a mixed and in an irregular manner, (ii) maintained traditionally and not intensively, (iii) relatively limited in using external inputs. Physically, the vegetation in the Lembo agroecosystem resembles the natural ecosystem because it has many and varied types of vegetation, consisting of a mixture of several types of fruit plants that grow together with various types of wild plants in the form of shrubs. Lembo agroecosystems are generally developed from former land for upland paddy fields, managed using a shifting cultivation system.

Soil fertility in East Kalimantan is relatively low for agroecosystem development (Bruenig 2017; Manurung et al. 2018). With the existence of a very fertile tropical rain forest, if converted into an agroecosystem, the status of soil fertility will drop drastically. An example is a conversion of forest to upland rice land, in a slash and burn manner. Fertile tropical rainforest ecosystems result from a longterm succession of natural ecosystems with closed nutrient cycles, but their fertility will drop drastically if converted into upland rice agroecosystems (Funakawa et al. 2009).

The development process of the Lembo agroecosystem has resembled the natural succession process of tropical rainforest formation. Therefore, the Lembo agroecosystem is developed by planting mixed fruit crops on former upland paddy fields. Traditional maintenance in terms of mowing the scrub and wild vegetation, just carried out during the planting cycle of upland rice in the following planting season or if fruit trees are entering the flowering season until the fruit harvest. Then left untreated until the next fruiting season. Based on the development process of the Lembo agroecosystem, which resembles the natural succession of tropical rain forest ecosystem development, the soil health status in the Lembo agroecosystem tends to increase from year to year (Setyawan 2010; Yassir 2012). 
Soil health is the capacity of soil to function as a vital living system, within the ecosystem and land-use boundaries, to sustain plant and animal productivity, maintain or enhance water and air quality, and promote plant and animal health (Doran and Zeiss 2000). Furthermore, Doran (2002) introduce three criteria for indicators of soil quality and health relate mainly to (i) their utility in defining ecosystem processes and in integrating physical, chemical, and biological properties; (ii) their sensitivity to management and climatic variations; and (iii) their accessibility and utility to agricultural specialists, producers, conservationists, and policymakers. Concerning agroecosystem management, Laishram et al. (2012) review soil quality and soil health deal with the adverse effects of plant input utility.

Soil health status, in general, could be determined based on the elements of physical fertility, chemical fertility, and biological fertility (Bulluck et al. 2002; Cardoso and Kuyper 2006; Chourasiya et al. 2017). The three elements that determine soil fertility have an interaction response with one another. Still, the element of biological fertility is an indicator of soil quality that can provide an active response in the form of soil micro-flora and fauna contained in the rhizosphere layer. Characteristics of natural ecosystems have very high soil biotic diversity as an element of biological fertility, and on the other hand, agroecosystems have relatively low soil biotic diversity (Yeates and Bird 1994; Swibawa and Aeny 2010; Maikhuri and Rao 2012).

Results of some studies showed that the level of soil biotic diversity could be used as an indicator of soil health status (Neher 2001), and poorly managed agroecosystems will cause a decrease in soil health status (Sanchez et al. 2003; Duoang et al. 2014). According to Yeates and Bongers (1999) and Devi (2020), nematodes as soil biotic elements can be used as a bioindicator to assess the soil health status, because nematodes have several trophic groups that occupy all positions in the micro food web in the rhizosphere ecosystem. There is a small portion of the nematode community occupies the trophic group of the plant feeder and harms plant, but most of the nematode community occupies the trophic groups as fungivores, bacterivores, carnivores, and omnivores that maintain stability in the rhizosphere (Moura and Franzener 2017). Those trophic groups of most nematode communities could play a role in increasing soil health status by increasing certain plant nutrients according to the type of nematode food source of each trophic group member (Yeates et al. 2009).

Based on the background, this study aimed to determine the soil health status of the Lembo agroecosystem, using the diversity indices and maturity indices as the evaluation indicators. The results of this study can be used as a consideration to determine the soil health status of the Lembo agroecosystem, determine the pest status of plantparasitic nematodes in the Lembo agroecosystem, and the alternative standard for the evaluation of soil health status in other agroecosystems by using nematodes diversity indices as the evaluation indicators.

\section{MATERIALS AND METHODS}

\section{Study site}

The Lembo agroecosystem (LA) used as the site of this research is located at Resak Village, Bongan Sub-district, West Kutai District, East Kalimantan Province (Figure 1). The site was determined based on the criteria that the Lembo agroecosystem as the main object of the study, located close to the oil palm plantation (OPP) which is used as the comparison agroecosystem.

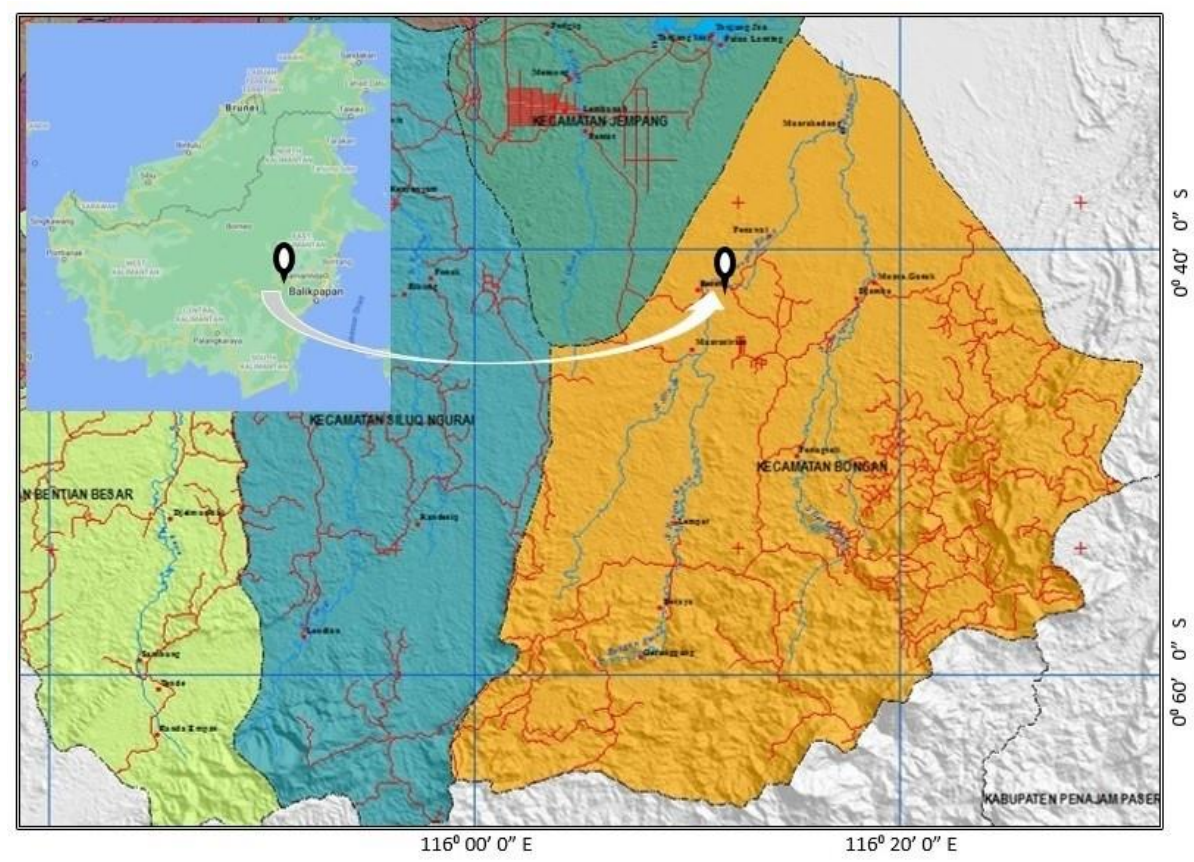

Figure 1. Map of study site in Resak Village, Bongan Sub-district, West Kutai District of East Kalimantan Province, Indonesia (Dinata 2021) 
So that both agroecosystems have relatively no different environmental conditions, in terms of soil types, climatic conditions, altitudes, and latitude. Lembo is an agroecosystem managed traditionally and approaches natural ecosystems. On the other hand, OPP is an agroecosystem managed intensively and uses a lot of external input.

The environmental conditions of LA and OPP agroecosystem situated just $45^{\prime}$ south of the equator and between $116^{\circ} 00^{\prime}-116^{\circ} 20^{\prime} \mathrm{E}$ (Figure 1), about 100-150 m above sea level, soil type mostly silty-loam, average monthly precipitation $200 \mathrm{~mm}(91.80-282.00 \mathrm{~mm})$, average air temperature $30^{\circ} \mathrm{C}\left(22.30-36.20^{\circ} \mathrm{C}\right)$, and average air humidity $75 \%$ (39-99\%) (Dinata 2021).

Based on the agroecosystem management, farmers clean their Lembo for just about three months a year by means of mowing the scrub and wild vegetation without soil tillage activities and external production inputs. Whereas, OPP agroecosystem was managed intensively, starting with the heavy land clearing, regular planting arrangement of monoculture oil palm as the main crop, height external input in terms of inorganic fertilizers and pesticides, and intensive weed control using herbicide.

\section{Procedures}

Soil sampling

Soil sampling is following the vertical distribution of crop roots (from $0-90 \mathrm{~cm}$ ), and divided into three layers of soil sample depth: layer $1(\mathrm{~L} 1)=0-30 \mathrm{~cm}$, layer $2(\mathrm{~L} 2)=$ $30-60 \mathrm{~cm}$, and layer $3(\mathrm{~L} 3)=60-90 \mathrm{~cm}$. The sampling point in the experimental field was arranged in a zigzag pattern (Schomaker and Been 2006) and 9 sampling points were assigned for each sampling unit. There are six sampling units for both agroecosystems, three sampling units each for LA and OPP. Soil sampling was carried out using a drilling technique, at each drilling sampling point, soil samples were collected from three layers of depth (L1, L2, and L3) and $300 \mathrm{~g}$ of soil sample was obtained from each layer. So that from each sampling unit $8,100 \mathrm{~g}$ of soil sample were collected (300 g sample $\mathrm{g}^{-1}$ x 3 soil layers depth $\mathrm{x} 9$ sampling points). So a total of almost 50,000 g soil samples were collected from all six sampling units of LA and OPP. Each soil sample was put in a plastic bag and equipped with description notes, then stored in a cool box and taken to the laboratory for nematode extraction.

\section{Nematode extraction and identification}

Nematode extraction from soil samples used the modified Baermann funnel method (Eisenback 2003; Forge and Kimpinski 2008). To prepare the extraction of nematodes, soil samples were cleaned of garbage and organic matter, the hose and plastic funnel (4-inch diameter) are washed and clean up, so that the soil sample, which has a silty loam texture can be spread evenly over the tissue paper supported by wire netting and put on the funnel. Soil samples from the same soil layer depth for each sampling unit were composited, then taken three samples (100 $\mathrm{g}$ each) for extraction processing using the Baermann funnel method and incubated for $3 \times 24$ hours. Nematodes in the extracted filtrate were gathered every 24 hours in three consecutive days. The nematodes in the extracted filtrate are then relaxing by gradual heating and fixed with a 4\% formalin solution (Ryss 2017). Furthermore, observations were made to identify the nematode genera and count the nematode community of each genus found. Nematodes genera identification was done based on morphological characters by using pictorial keys (Eisenback 2002; Mekete et al. 2012; Mai and Lyon 1975; Panesar and Marshall 2003)

\section{Data analyses}

The nematode diversity measurements were used to determine the soil health status in Lembo agroecosystem (LA) are the Shannon-Wiener index $\left(H^{\prime}\right)$, evenness index $\left(E_{H}\right)$, genera richness index $(G R)$, dominance index $(\lambda)$, and supported by maturity indices ( $\Sigma \mathrm{MI}$, PPI, MI, MI2-5, PPI/MI) and absolute abundance of nematodes. As a comparison to assess the soil health status in the Lembo agroecosystem, oil palm plantations (OPP) that are located close to each other are used.

The data of nematodes genera and abundance of each genus data were analyzed using diversity measurements and supported by maturity indices and nematodes abundance. The nematode abundance was presented in the absolute abundance and genera abundance. The diversity measurements used (Neher and Darby 2009) are as follows.

$\begin{array}{ll}\text { Shannon-Wiener index }\left(H^{\prime}\right), & H^{\prime}=-\Sigma\left(p_{\mathbf{i}} \cdot \ln p_{\mathbf{i}}\right) \\ \text { Evenness index }\left(E_{H}\right), & E_{H}=H^{\prime} / \ln S \\ \text { Genera richness index }(\mathrm{GR}) & \mathrm{GR}=S-1 / \ln N \\ \text { Dominance index }(\lambda) & \lambda=\Sigma p_{\mathbf{i}}^{2}\end{array}$

Where:

$p \mathrm{i}$ is the proportion of individuals in the $i$ th taxon

$S$ is the number of taxa

$N$ is the number of individuals identified.

The nematode Maturity Indices used (Yeates and Bongers 1999) are as follows: (i) Total maturity index $(\Sigma \mathrm{MI})=\Sigma p_{\mathbf{i}} \cdot c-p_{\mathbf{i}}$; for all nematodes genera. (ii) Plant parasitic maturity index $(\mathrm{PPI})=\Sigma p_{\mathbf{i}} c-p_{\mathbf{i}}$; for plant parasitic nematodes genera only. (iii) Non-plant parasitic maturity index $(\mathrm{MI})=\Sigma p_{\mathbf{i}} \cdot c-p_{\mathbf{i}}$; for non-plant parasitic nematodes genera only. (iv) Total maturity index of c-p2-5 $\left(\Sigma \mathrm{MI}_{2-5}\right)=$ $\Sigma p_{\mathbf{i}} . c-p_{\mathbf{i}}$; for nematodes genera group of c-p2-5 only. (v) PPI/MI ratio. Where: $p_{\mathrm{i}}$ is the proportion of the $i$ th taxon; $c$ $p \mathrm{i}$ is the c-p value of the $i$ th taxon. 


\section{RESULTS AND DISCUSSION}

\section{Nematodes abundance}

Nematodes absolute abundance and vertical distribution.

Nematode community abundance is a variable that describes absolute abundance. The results showed that the mean abundance of the nematode community in LA was two times higher than that of the nematode community in OPP. However, the vertical distribution of nematode communities in both agroecosystems has the same trend, which is decreasing from the topsoil layer $(0-30 \mathrm{~cm})$ to the soil layer below $(30-60 \mathrm{~cm}$ and $60-90 \mathrm{~cm})$. The ratio of nematode community abundance in LA at the topsoil (0-30 $\mathrm{cm})$, middle soil layer $(30-60 \mathrm{~cm})$, and bottom soil layer $(60-90 \mathrm{~cm})$ reached $254 \%, 280 \%$, and $389 \%$, respectively compared to the abundance of the nematode community in OPP. The decrease in nematode community abundance from the topsoil to a depth of $60-90 \mathrm{~cm}$ reached $84 \%$ in LA and $90 \%$ in OPP (Figure 2).

\section{Genera abundance.}

Nematode genera abundance was arranged by the abundance of the nematode community for each genus. There are ten genera of nematodes found in LA, and only five genera of nematodes found in OPP. The community abundance of each nematode's genus in LA was always higher than the community abundance in OPP. The three highest abundance of nematode genera in both agroecosystems were Dorylaimus, Pratylenchus, and Rhabditis, respectively. Then, followed by Paratylenchus and Cephalobus in OPP, and followed by Cephalobus, Aphelenchus, and the rest five genera in LA (Figure 3). The ratio of nematode community abundance in LA was higher than the community abundance in OPP as shown by the genus of Dorylaimus (214\%), Pratylenchus (208\%), Rhabditis (186\%), and Cephalobus (308\%), respectively.

\section{Diversity measurements}

The following four indices can simultaneously explain the condition of nematode genera diversity in LA with OPP as a comparison of the agroecosystem.

\section{Shannon-Wiener index ( $\left.H^{\prime}\right)$.}

Based on the $H^{\prime}$ value, it is known that the diversity of nematode genera in LA is higher than the diversity of nematode genera in OPP (Figure 4). The determinants leading to this difference were the community abundance of each genus and the genera number in those agroecosystems. The nematodes community abundance AL/OPP ratio in each soil sample layer reached $\geq 186 \%$, and the number of genera found in LA was twice as amount as that found in OPP (Figure 2). However, the $H^{\prime}$ value in both agroecosystems has the same trend: the highest was noted at the topsoil layer $(0-30 \mathrm{~cm})$ and decreasing in the soil layer below (30-60 cm and 60-90 $\mathrm{cm})$. The ratio of $H^{\prime}$ value in LA was $30 \%$ to $43 \%$ higher than the $H^{\prime}$ value in OPP.

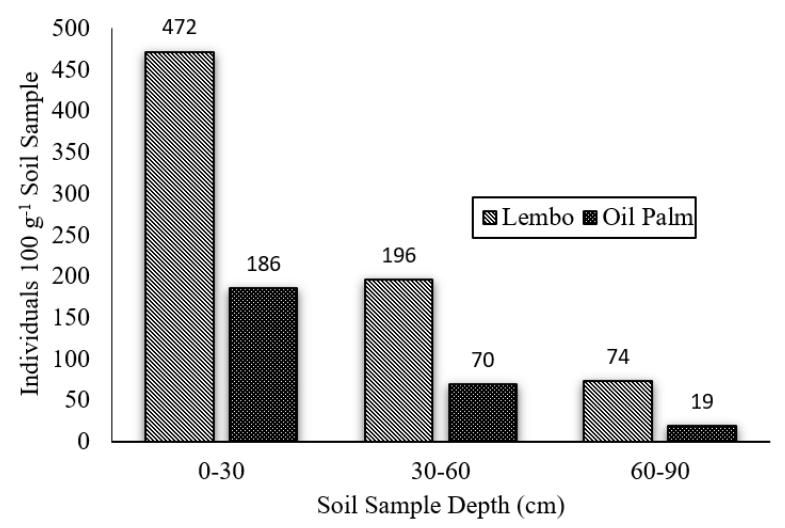

Figure 2. The average of nematodes absolute abundance at the oil palm plantation and Lembo agroecosystem.

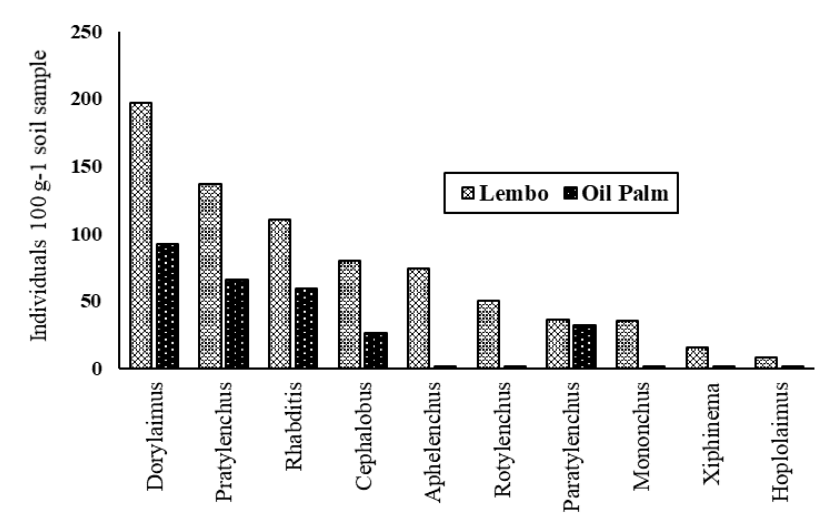

Figure 3. The nematodes genera abundance at the oil palm plantation and Lembo agroecosystem.

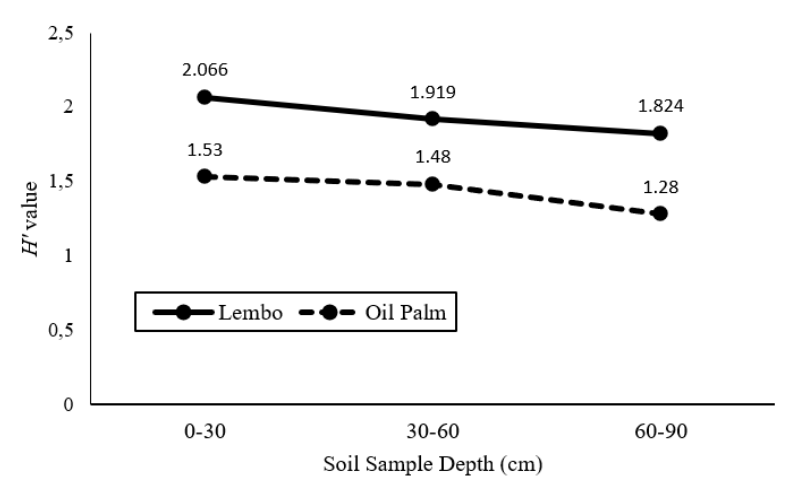

Figure 4. The Shannon-Wiener index $\left(H^{\prime}\right)$ of nematodes at the oil palm plantation and Lembo agroecosystem 
Evenness index $\left(E_{H}\right)$.

The evenness index $\left(E_{H}\right)$ of nematode genera in this study is a standardization of the diversity index $\left(H^{\prime}\right)$ using the maximum diversity index $\left(H^{\prime}{ }_{\max }\right)$ that can be achieved by all nematode genera, which is found in LA and OPP. Based on the $E_{H}$ value, it is assumed that the distribution of nematode genera in OPP is more evenly distributed than that of the nematode genera in LA. This is due to the maximum diversity index value $\left(H^{\prime}{ }_{\max }\right)$ as the divider of $H^{\prime}$ to determine the $E_{H}$ value. The value of $H^{\prime}{ }_{\max }$ in LA is twice as large as the value of $H^{\prime}{ }_{\text {max }}$ in OPP. However, the $E_{H}$ value in both agroecosystems has the same trend, namely the high $E_{H}$ value in the topsoil layer $(0-30 \mathrm{~cm})$ and tends to decrease in the deeper soil layers $(30-60 \mathrm{~cm}$ and $60-90 \mathrm{~cm}$ ) (Figure 5). This is because in the deeper soil layer the $H^{\prime}$ value decreases (Figure 4), while the number of genera found in both agroecosystems is relatively unchanged.

\section{Genera richness index (GR)}

Another diversity measurement is the nematode genera richness index (GR). This GR shows the number of genera in LA and OPP after being corrected by the total community abundance of nematode genera in each agroecosystem. According to the data obtained, the nematode genera found in LA were more than that found in OPP. This is because the GR value in LA is higher than that of GR in OPP (Figure 6). An interesting fact shown by GR is that the trend of GR value increases with increasing soil layer depth. This event is caused by a decrease in the abundance of the nematode community in the deeper soil layers, while the number of nematode genera found in all soil layers is relatively unchanged.

\section{Dominance index.}

As well as the role of the GR index, the dominance index $(\lambda)$ explains the diversity status of the presence of nematodes in LA and OPP. Relevant to the values of $H^{\prime}$ and $E_{H}$, which are high in the topsoil layer $(0-30 \mathrm{~cm})$ and decrease in the deeper soil layers $(30-60 \mathrm{~cm}$ and 60-90 cm) (Figs. 4 and 5). The decrease in the diversity index in LA and OPP in this study was triggered by an increase in the dominance of the genus Dorylaimus. The rate of increase in the value of $\lambda$ in OPP tends to be higher than that in LA, but the value of $\lambda$ in LA is still higher than the value of $\lambda$ in OPP for all soil layers (Figure 7).

\section{Maturity index}

Nematodes maturity index is a measure of the biological function of nematodes diversity measurement in the soil ecosystem by involving the $c-p$ value. Soil nematodes are categorized into a 1-5 colonizer-persister series, 'colonizer' nematodes at the lower end of the c-p scale are consider enrichment opportunist and therefore indicate resource availability, whereas 'persister' nematodes at the high end of the c-p scale indicate system stability, food web complexity, and connectance (Ferris and Bongers 2009).

The community abundance, c-p value, and feeding group of nematodes found in LA and OPP agroecosystems are presented in Table 1. Based on the c-p value, there are three nematodes genera under c-p 2 and c-p3 value, two genera under c-p4, and one genus each under c-p1 and cp5. However, based on the nematodes feeding group, there five genera are considered as herbivore, two genera as bacterivorous, and one genus each under fungivore, predator, and omnivore feeding group. The community abundance based on feeding group of non-herbivore nematodes is omnivores, bacterivores, fungivores, and predators, consecutively.

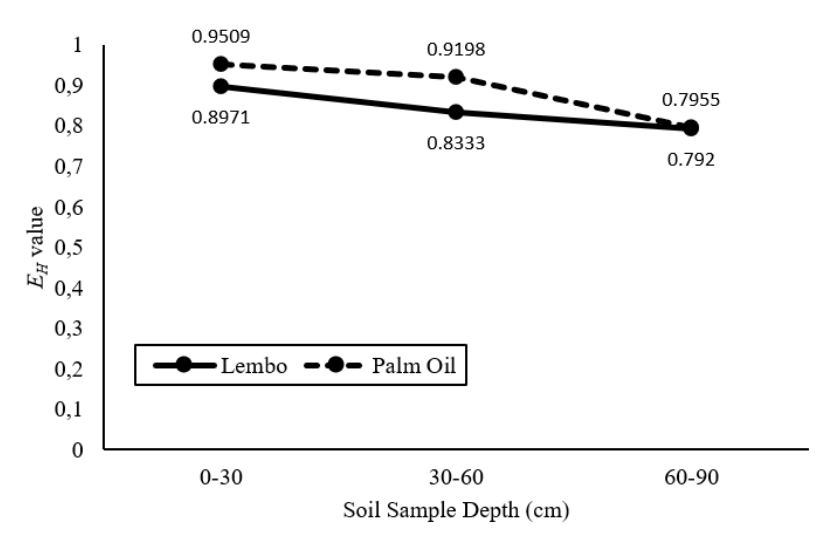

Figure 5. The nematodes evenness index $\left(E_{H}\right)$ at the oil palm plantation and Lembo agroecosystem

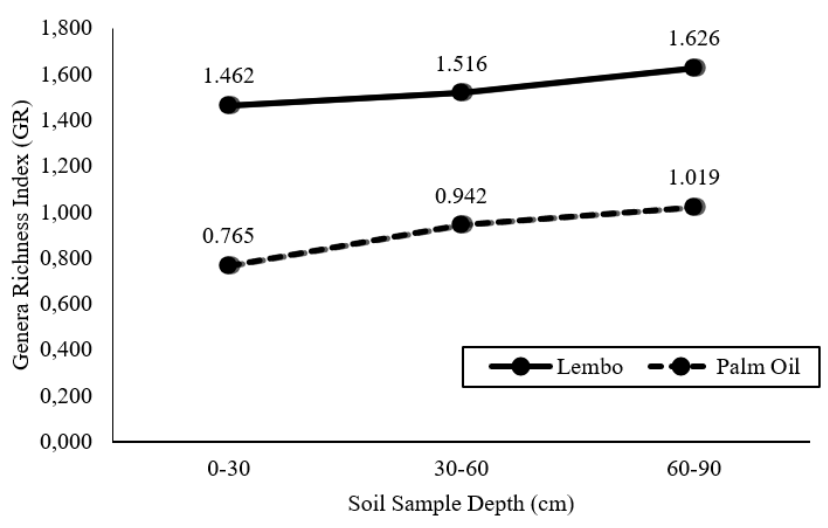

Figure 6. The nematodes genera richness index (GR) at the oil palm plantation and Lembo agroecosystem

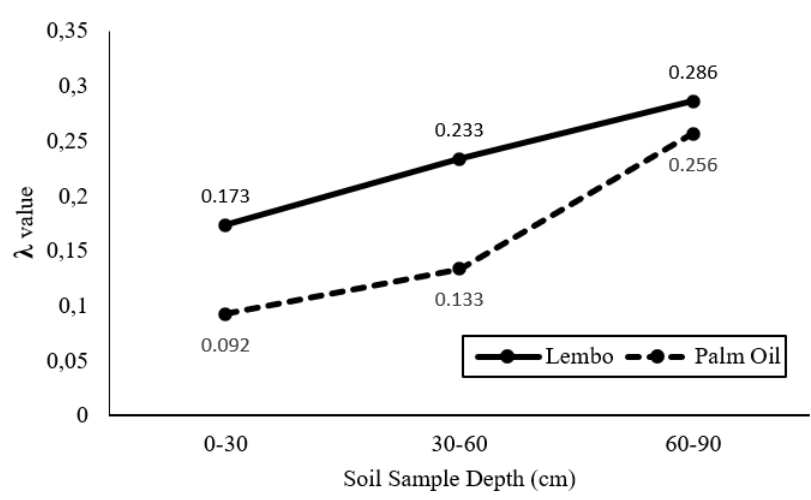

Figure 7. The nematodes dominance index $(\boldsymbol{\lambda})$ at the oil palm plantation and Lembo agroecosystem 
Table 1. The nematodes community abundance at LA and OPP in West Kutai District of East Kalimantan Province, Indonesia

\begin{tabular}{llccc}
\hline \multirow{2}{*}{ Nematode genus } & Feeding group & c-p value & \multicolumn{2}{c}{ Nematode abundance } \\
\cline { 3 - 5 } & & 1 & LA & OPP \\
\hline Rhabditis & Bacterivore & 2 & 110 & 59 \\
Cephalobus & Bacterivore & 2 & 80 & 26 \\
Aphelenchus & Fungivore & 2 & 34 & - \\
Paratylenchus & Herbivore & 3 & 137 & - \\
Pratylenchus & Herbivore & 3 & 50 & - \\
Rotylenchus & Herbivore & 3 & 8 & - \\
Hoplolaimus & Herbivore & 4 & 35 & - \\
Mononchus & Predator & 4 & 197 & - \\
Dorylaimus & Omnivore & 5 & 15 & - \\
Xiphinema & Herbivore & & \\
\hline
\end{tabular}

Table 2. The maturity indices values of soil nematodes at LA and OPP in West Kutai District of East Kalimantan Province, Indonesia

\begin{tabular}{|c|c|c|c|c|c|c|c|c|}
\hline \multirow{2}{*}{$\begin{array}{l}\text { Nematode } \\
\text { c-p group }\end{array}$} & \multicolumn{8}{|c|}{ Nematode community abundance } \\
\hline & $0-30 \mathrm{~cm}$ & $30-60 \mathrm{~cm}$ & $60-90 \mathrm{~cm}$ & Total & $0-30 \mathrm{~cm}$ & $30-60 \mathrm{~cm}$ & $60-90 \mathrm{~cm}$ & Total \\
\hline & \multicolumn{4}{|c|}{ Lembo Agroecosystem } & \multicolumn{4}{|c|}{ Oil Palm Plantation } \\
\hline 1 & 66 & 32 & 12 & 110 & 38 & 17 & 4 & 59 \\
\hline 2 & 97 & 42 & 15 & 154 & 18 & 6 & 2 & 26 \\
\hline 3 & 154 & 57 & 20 & 231 & 69 & 24 & 5 & 98 \\
\hline 4 & 141 & 64 & 27 & 232 & 61 & 23 & 8 & 92 \\
\hline 5 & 14 & 1 & - & 15 & - & - & - & 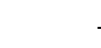 \\
\hline \multirow[t]{2}{*}{ Total } & 472 & 196 & 74 & 742 & 186 & 70 & 19 & 275 \\
\hline & \multicolumn{8}{|c|}{ Maturity Indices } \\
\hline$\Sigma \mathrm{MI}$ & 2.873 & 2.796 & 2.838 & 2.849 & 2.823 & 2.757 & 2.895 & 2.811 \\
\hline PPI & 3.167 & 3.034 & 3.000 & 3.122 & 3.000 & 3.000 & 3.000 & 3.000 \\
\hline MI & 2.711 & 2.696 & 2.778 & 2.714 & 2.718 & 2.630 & 2.857 & 2.706 \\
\hline $\mathrm{MI}_{2-5}$ & 3.177 & 3.146 & 3.194 & 3.171 & 3.291 & 3.321 & 3.400 & 3.306 \\
\hline PPI/MI & 1.17 & 1.13 & 1.08 & 1.15 & 1.10 & 1.14 & 1.05 & 1.11 \\
\hline
\end{tabular}

The role of the nematode maturity indices ( $\Sigma \mathrm{MI}, \mathrm{MI}$, PPI, $\mathrm{MI}_{2-5}$, and PPI/MI) are very important in explaining the relationship between diversity index and soil health status in LA and using OPP agroecosystem as a comparison. Therefore, based on several nematode maturity index values, the state of soil health can be seen, whether it is damaged, in the process of repairing, or in a stable state. In general, based on the maturity index values, both LA and OPP environments are relatively not so different. Based on the concept of maturity index, in condition $H^{\prime}$ reaches the maximum value and is evenly distributed, the value of $\Sigma \mathrm{MI}$ is close to 3.0 , and the average value of $\Sigma \mathrm{MI}$ is 2.5 . So it can be stated that the LA and POP environments in this study are in good condition, meaning that they have a stable condition with a value of $\Sigma$ MI $>2.5$ and close to 3.0 (Table 2). This shows that the nematode genera of the opportunist group (c-p1) have a lower community abundance than the nematodes of the cp2-5 genera, representing the nematode genera of the predatory and omnivore groups.

The PPI/MI ratio is a derivative of nematode maturity indices which is interesting to note from the aspect of plant-parasitic nematode control. The high value of the $\mathrm{PPI} / \mathrm{MI}$ ratio is due to the low MI value because the present a genus of opportunistic nematodes (c-p1) whose community reaches $15 \%$ in LA and $21 \%$ in OPP (Table 2).
However, if calculated based on the PPI/MI2-5 ratio, the PPI/MI2-5 ratio values will be obtained $<1$, so that the pest status of plant-parasitic nematode in both agroecosystems is relatively low. This fact is supported by the role of group members of c-p2-5 nematode genera (MI2-5) are predators and omnivores that play a role in controlling plant-parasitic nematodes.

\section{Discussion}

The presence of nematodes in the soil ecosystem is an important element of soil biological fertility determinants. Nematodes have trophic groups that are present in all positions of the micro food web in the rhizosphere ecosystem. So that nematodes living in the rhizosphere are an ideal element to be used as an indicator of the soil health status (Ferris et al. 2001; Bileva et al. 2014; Moura and Franzener 2017). The implementation of the nematode as an indicator for determining soil health status could be done by using diversity indices and maturity indices of nematode genera or species (Ferris and Bongers 2009). Diversity indices determined changes or differences in nematode diversity at different places, while maturity indices are used to determine the direction of change or development status of nematodes community from a disturbance to a stable condition of an ecosystem (Yeates and Bongers 1999). 
Nematodes maturity indices values of $\Sigma \mathrm{MI}, \mathrm{MI}, \mathrm{MI}_{2-5}$, PPI, and PPI/MI-ratio have relatively no difference in LA and OPP agroecosystems based on environmental health criteria propose by Ürkmez et al. (2014). So, it could consider that both agroecosystems relatively have the same soil health status (Table 2). Based on the concept of nematode maturity index, when the diversity index value $\left(H^{\prime}\right)$ reaches a maximum, and the $E_{\boldsymbol{H}}$ value is close to $100 \%$, the $\Sigma$ MI value will be close to 3.0 (Ferris and Bongers 2009). This study indicates that the maturity indices values in LA and OPP are close to 3.0, even more than 3.0 for the index value of $\mathrm{MI}_{2}$-5. Following the environmental health criteria established by Ürkmez et al. (2014), the environmental health criteria in terms of soil health status in LA and OPP are good because it has an MI value > 2.6. Even, there is the MI value > 2.8 for the deepest soil layer $(60-90 \mathrm{~cm})$ of OPP, its means include in the high category. Due to the community of the nematode genera of c-p2 members in that layer, it has decreased drastically.

The soil health status in LA and OPP can be further explained by breaking down the parameter values of $\mathrm{MI}_{2-5}$ into $\mathrm{MI}_{2}$ and $\mathrm{MI}_{4}$. The nematode genera including $\mathrm{MI}_{2}$ are the c-p2 member nematode genera, they can live in all environmental conditions, both in conditions of abundant and limited resources, and are very tolerant to pollutants and disturbances. They are mainly fungivores, bacterivores, and some are predators (Ferris and Bongers 2009). Meanwhile, the nematode genera including in $\mathrm{MI}_{4}$ is the cp4 member nematode genera, they are very sensitive to pollutants, in general, they are predators, omnivores, and some are bacterivores (Ferris and Bongers 2009). The average community abundance of nematode genera including c-p2 members in LA reaches $21 \%$ and only $9 \%$ in OPP. Whereas, the average community abundance of nematode genera including c-p4 members in LA reaches $32 \%$ and reaches $33 \%$ in OPP. Based on community abundance data of nematode genera groups of c-p2 and cp4 and environmental health criteria established by Ürkmez et al. (2014), the environmental health criteria in terms of soil health status in LA and OPP is high (c-p2 $\leq 50 \%$ and c-p4 > 10\%).

Determination of soil health status in LA and OPP can use the maturity index $\mathrm{MI}_{1}$, which consists of nematode genera group c-p1. The characteristics of the nematode genera members of the c-p1 group are nematodes that are tolerant of pollutants. Their community grows very rapidly as colonizers in food-enriched conditions or environments rich in organic matter decomposition products. They mainly serve as bacterial feeders (Ferris and Bongers 2009). The proportion of community abundance of the c-p1 group nematode genera in LA was lower $(15 \%)$ than that in OPP (21\%). However, the absolute community abundance of the c-p1 group nematode genera in LA was $86 \%$ higher than the community abundance in OPP (Table 2). The high percentage of community abundance of the c-p1 group nematode genera in OPP $(21 \%)$ is related to foodenrichment (Pan et al. 2015; Ferris et al. 2001) through periodic fertilizer application, and the negative impact occurs on the nematode genera group c-p3-5 which is very sensitive to pollutants (Duong et al. 2014) so that the community is low. In contrast to LA, the presence of the cp1 group nematode genera uses food resources from the decomposition of organic matter from leaf litter and plant twigs that fall to the soil surface (Krashevska et al. 2019), but community development is controlled by predators, and omnivores from member nematode genera group c-p4-5 (Sholeha et al. 2017; Steel et al. 2018). Hence, the community abundance of nematode genera of c-p1 group in LA is relatively low or in a stable condition of the ecosystem.

Plant-parasitic nematodes (PPI) are important to consider because this group can cause damage to plants. Based on several research results, it is known that the $\mathrm{PPI} / \mathrm{MI}$ ratio is a very sensitive indicator influenced by enrichment (Bongers et al. 1997). The high PPI/MI ratio values in LA and OPP in this study indicate that the availability of nutrients in both agroecosystems is quite high, according to the statement of Ferris and Bongers (2009) that the PPI/MI ratio value will be higher on land with abundant nutrients compared to soil conditions that are deficient in nutrients. The statement stated above is supported by the results of studies on fertilizer treatment which increases the community of plant-parasitic nematodes (Neher 2001; Okae-Anti et al. 2013) because applying fertilizers to plants will increase plant vigor and support the availability of food sources for plant-parasitic nematodes. The pest status of plant-parasitic nematode on LA and OPP in this study, if evaluated based on the PPI/MI ratio, seemed high $(>1.0)$, but the high $\mathrm{PPI} / \mathrm{MI}$ ratio value was the effect of the inclusion of the c-p1 genera group in MI value. As is known, the c-p1 member nematodes are bacterial feeders and do not play a role in controlling plantparasitic nematodes, while those that play a role in controlling plant-parasitic nematodes are predators and omnivores nematodes of c-p2-5 member. If evaluated based on the PPI/MI2-5 ratio, the value is low (Table 2), which means that the pest status of plant-parasitic nematodes in both agroecosystems is also low. It was also lower due to not all existing plant-parasitic nematodes prefer the available hosts as the main crop in the agroecosystem.

In contrast to the maturity indices parameter, based on the diversity indies parameter and abundance, all parameter values in LA are higher than the parameter values in OPP, except for the evenness parameter $\left(E_{H}\right)$ in LA, which has a relatively low value compared to OPP (Figure 5). Therefore, the formula used to obtain $E_{\boldsymbol{H}}$ is $E_{\boldsymbol{H}}=H^{\prime} / \mathrm{ln} S$ (Yeates and Bongers 1999), and $S$ is the number of genera. The genera number in LA is twice as much as that of OPP, while the $H^{\prime}$ values are not much different so that the $E_{\boldsymbol{H}}$ value in OPP is higher than LA.

The greater number of genera and the higher community abundance in LA than OPP were the main factors that influenced the high values of the indicators of diversity indices and abundance in LA. This condition is relevant to research results which show that the density of nematode community in the soil is higher in natural ecosystems than in ecosystems managed for various human 
activities, including OPP agroecosystems (Yeates and Bird 1994; Swibawa and Aeny 2010; Krashevska 2019).

In conclusion, our study found that the Lembo agroecosystems (LA) had good soil health status according to the criteria for maturity indices $\left(\Sigma \mathrm{MI}, \mathrm{MI}, \mathrm{MI}_{2-5}, \mathrm{PPI}\right.$, and PPI/MI ratio), and the status was better than that of oil palm plantation (OPP) based on criteria for diversity indices $\left(H^{\prime}, \mathrm{GR}\right.$, and $\left.\lambda\right)$, absolute abundance and genera abundance of nematodes. So that the LA is an agroecosystem model that can be developed in East Kalimantan, and to increase its productivity it is necessary to apply better management and arrangement of fruit plants that are more reliable and more appropriate based on mixcropping in agronomic principles. In terms of the pest status of plant-parasitic nematodes, LA is relatively safe because the presence of plant-parasitic nematodes is stabilized by the presence of predatory and omnivore nematode groups.

\section{ACKNOWLEDGEMENTS}

This research received no specific grant from any funding agency in the public, commercial, or non-profit sectors. We acknowledge the Head of Plant Pest and Diseases Laboratory, Faculty of Agriculture Mulawarman University for facilities and equipment supports.

\section{REFERENCES}

Bach EM, Ramirez KS, Fraser TD, Wall DH. 2020. Soil biodiversity integrates solutions for a sustainable future. Sustainability 12 (7): 120 FOI: $10.3390 /$ su 12072662

Bileva T, Stefanova V, Haytova D. 2014. Assessment of nematodes as bioindicators of soil health in agroecosystems. Turkish J Agric Nat Sci. Special Issue 1: 568-573

Bongers T, van der Meulen H, Korthals G. 1997. Inverse relationship between the nematode maturity index and plant parasite index under enriched nutrient conditions. Appl Soil Ecol 6 (2): 195-199 DOI: .1016/S0929-1393(96)00136-9.

Bruenig EF. 2017. Conservation and Management of Tropical Rainforests: An Integrated Approach to Sustainability. 2nd ed. CABI, Oxfordshire, UK

Bulluck LR, Brosius M, Evanylo GK, Ristaino JB. 2002. Organic and synthetic fertility amendments influence soil microbial, physical, and chemical properties on organic and conventional farms. Appl Soil Ecol 19: 147-160.

Cardoso IM, Kuyper TW. 2006. Mycorrhizas and tropical soil fertility. Agric Ecosyst Environ 116 (1-2): 72-84. DOI: 10.1016/j.agee.2006.03.011.

Chourasiya D, Sharma MP, Maheshwari HS, Ramesh A, Sharma SK, Adhya TK. 2017. Microbial Diversity and Soil Health in Tropical Agroecosystems. In: Adhya TK, Mishra BB, Annapurna K, Kumar D, Kumar VU (eds.) Advances in Soil Microbiology: Recent Trends and Future Prospects, Volume 2: Soil-Microbe-Plant Interaction. Springer Nature Singapore, Singapore.

Devi G. 2020. Nematodes as environmental indicator. Intl J Curr Res 12 (05): 11699-11705. DOI: 10.24941/ijcr .38782.05.2020

Dinata YEF. 2021. Kutai Barat District in Figures 2021. BPS Statistics of Kutai Barat District, Kutai Barat District.

Doran JW, Zeiss MR. 2000. Soil health and sustainability: managing the biotic component of soil quality. Appl Soil Ecol 15: 3-11.

Doran JW. 2002. Soil health and global sustainability: translating science into practice. Agric Ecosyst Environ 88: 119-127.

Duong DH, Le TPA, Bui, TTN, Ngo XQ, Nguyen DT, Nguyen HH, Nguyen, VT. 2014. Nematode communities act as bio-indicator of status and processes of an agricultural soil ecosystem in Thanh An, Binh Phuoc Province. J Viet Environ 6 (3): 227-232.

Eisenback JD. 2002. Identification Guides for the Most Common Genera of Plant-Parasitic Nematodes. Mactode Publications, Blacksburg.

Eisenback JD. 2003. Nematology, Laboratory Investigations, Morphology and Taxonomy. Mactode Publications. Indian Meadow Drive, Blacksburg.

Ferris H, Bongers B, de Goede RGM. 2001. A framework for soil food web diagnostics: extension of the nematode faunal analysis concept. Appl Soil Ecol 18: 13-29.

Ferris H, Bongers T. 2009. Indices Developed Specifically for Analysis of Nematode Assemblages. In: Wilson MJ, Kakouli-Duarte T (eds.). Nematodes as Environmental Indicators. CABI, Oxfordshire, UK.

Forge TA, and Kimpinski J. 2008. Nematodes. In: Carter MR, Gregorich EG (eds.). Soil Sampling and Methods of Analysis. CRC Press, Boca Raton, FL.

Funakawa S, Makhrawie M, Pulunggono HB. 2009. Soil fertility status under shifting cultivation in East Kalimantan with special reference to mineralization patterns of labile organic matter. Plant Soil 319: 57-66. DOI: 10.1007/s11104-008-9849-0.

Krashevska V, Kudrin AA, Widyastuti R, Scheu S. 2019. Changes in nematode communities and functional diversity with the conversion of rainforest into rubber and oil palm plantations. Front Ecol Evol 13 (487): 1-10. DOI: 10.3389/fevo.2019.00487

Laishram J, Saxena KG, Maikhuri RK, Rao KS. 2012. Soil quality and soil health: a review. Int J Ecol Environ Sci 38 (1): 19-37.

Mai WF, Lyon HH. 1975. Pictorial key to genera of plant-parasitic nematodes. Comstock Publishing Associates, Cornell University Press. Ithaca, NY

Manurung H, Kustiawan W, Kusuma IW, and Marjenah. 2018. Evaluation of soil and leaves nutrients on the growth of cultivated tabatbarito (Ficusdeltoidea jack.) in Makroman Village, Sambutan Sub-district of East Kalimantan, Indonesia. IOP Conf Ser Earth Environ Sci 144 012017. DOI: 10.1088/1755-1315/144/1/012017.

Mekete T, Dababat A, Sekora N, Akyazi F, Abebe E. 2012. Identification key for agriculturally important plant-parasitic nematodes Prepared for the International Nematode Diagnosis and Identification Course 2012 - A manual for nematology, D.F. CIMMYT. Mexico.

Moura GS, Franzener G. 2017. Biodiversity of nematodes biological indicators of soil quality in the agroecosystems. Arq Inst Biol 84: 1-8.

Neher DA, Darby BJ. 2009. General Community Indices that can be used for Analysis of Nematode Assemblages. In: Wilson MJ and KakouliDuarte $\mathrm{T}$ (eds) Nematodes as Environmental Indicators. CABI, Oxfordshire, UK

Neher DA. 2001. Role of Nematodes in Soil Health and Their Use as Indicators. J Nematol 33 (4): 161-168.

Okae-Anti D, deGraft-Etsison V, Adu-Bitherman P, Iddriss ARM. 2013. Effect of inorganic fertilizers and palm bunch ash on nematode population dynamics and plantain yield in a haplic lixisol. Intl J Agric Policy Res 1 (8): 205-209.

Pan F, Han X, McLaughlin NB, Han X, Li C, Zhao D, Zhan L, Xu Y. 2015. Effect of long-term fertilization on free-living nematode community structure in Mollisols. J Soil Sci Plant Nutr 15 (1): 129141.

Panesar TS, Marshall VG. 2003. Monograph of Soil Nematodes from Coastal Douglas-fir Forests in British Columbia. Royal Roads University, Victoria.

Ryss AY. 2017. A simple express technique to process nematodes for collection slide mounts. J Nematol 49 (1): 27-32.

Sanchez PA, Palm CA, Buol SW. 2003. Fertility capability soil classification: a tool to help assess soil quality in the tropics. Geoderma 114: 157-185. DOI: 10.1016/S0016-7061(03)00040-5.

Schomaker CH, Been TH. 2006. Plant growth and population dynamics. In: Perry RN, Moens M (eds). Plant Nematology. 1st ed. CABI, Wallingford, UK.

Setyawan AD. 2010. Review: Biodiversity conservation strategy in a native perspective; case study of shifting cultivation at the Dayaks of Kalimantan. Nusantara Biosci 2 (2): 97-108.

Sholeha AR, Maharning AR, Nasution EK. 2017. Nematode community response to varied proportion of decomposing plant litter. Scr Biol 4 (3): 161-164. DOI: 10.20884/1.sb.2017.4.3.588

Steel H, Moens T, Vandecasteele B, Hendrickx F, De Neve S, Neher DA, Bert W. 2018. Factors influencing the nematode community during composting and nematode-based criteria for compost maturity. Ecol Indic 85: 409-421. 
Swibawa IG, Aeny TN. 2010. Nematode diversity in a range of land use types in Jambi Benchmark Indonesia. J Hama Penyakit Tumbuhan Tropika 10 (2): 162-171.

Ürkmez D, Sezgin M, Bat L. 2014. Use of nematode maturity index for the determination of ecological quality status: A case study from the Black Sea. J Black Sea / Mediterr Environ 20 (2): 96-107.

Yasir I. 2012. Soil Carbon Stocks and Changes upon Forest Regeneration in East Kalimantan, Indonesia. [Dissertation]. Wageningen University, Wageningen, Netherlands.
Yeates GW, Bird AF. 1994. Some observations on the influence of agricultural practices on the nematode faunae of some South Australian soils. Fundam Appl Nematol 17 (2): 133-145.

Yeates GW, Bongers T. 1999. Nematode diversity in agroecosystems. Agric Ecosyst Environ 74: 113-135.

Yeates GW, Ferris H, Moens T, Van der Putten WH. 2009. The role of nematodes in ecosystems. In: Wilson MJ, Kakouli-Duarte T (eds). Nematodes as Environmental Indicators. CABI, Oxfordshire, UK. 